\title{
New records of Rosenvingea (Scytosiphonaceae, Phaeophyceae) from the Philippines
}

\author{
Wilfred John E. Santiañez ${ }^{1,2^{*}}$ and John A. West ${ }^{3}$
}

\begin{abstract}
We describe herein the morpho-anatomy of the elusive brown alga Rosenvingea nhatrangensis (Scytosiphonaceae, Phaeophyceae) and add this species to the flora of both the Philippines and Malaysia. At present, only two Rosenvingea species ( $R$. intricata and $R$. orientalis) have been reported from both localities. We also report on the occurrence of $R$. australis in central Philippines based on molecular phylogenetic data, thus extending its distribution to the northern Pacific. First time account of the morphology of $R$. australis sporophyte under culture conditions is also provided.
\end{abstract}

Keywords: biodiversity, brown algae, Malaysia, Rosenvingea australis, Rosenvingea nhatrangensis, taxonomy

\section{Introduction}

Members of the genus Rosenvingea Børgesen (Scytosiphonaceae, Phaeophyceae) are tropical to subtropical brown seaweeds distinguished by their erect, dichotomous or alternately branched, cylindrical to somewhat compressed, hollow thalli with plurangia forming surface sori (Børgesen 1914, Norris 2010, West et al. 2010, Lee et al. 2014, Huisman et al. 2018). Branches, which are free in most species or coadhering in some, along with their branching patterns are primarily used as taxonomic criteria for segregating the different taxa in this genus. Presently, there are eight known Rosenvingea species worldwide (Guiry and Guiry 2019): the generitype $R$. sanctae-crucis Børgesen, $R$. fastigiata (Zanardini) Børgesen, R. intricata (J. Agardh) Børgesen, R. orientalis (J. Agardh) Børgesen (Børgesen 1914), R. floridana (W.R. Taylor) W.R. Taylor (Taylor 1955), R. nhatrangensis E.Y. Dawson (Dawson 1954), R. antillarum (P. Crouan \& H. Crouan) M.J. Wynne (Wynne 1997) and R. australis Huisman, G.H. Boo \&

\footnotetext{
${ }^{1}$ The Marine Science Institute, University of the Philippines, Diliman, Quezon City 1101, Philippines,

${ }^{2}$ Department of Natural History Sciences, Graduate School of Science, Hokkaido University, Sapporo, Japan;

${ }^{3}$ School of Botany, University of Melbourne, Parkville, Victoria 3010, Australia

*Corresponding email: wjsantianez@msi.upd.edu.ph
}

Date Submitted: 23 June 2019

Date Accepted: 19 July 2019
S.M. Boo (Huisman et al. 2018).

The taxonomy of Rosenvingea remains problematic despite recent studies utilizing molecular techniques; although, this is understandable considering that only three species (i.e., $R$. intricata, $R$. australis, and $R$. orientalis) have been included in molecular studies (West et al. 2010, Lee et al. 2014, Huisman et al. 2018, Santiañez et al. 2018a). Among the most interesting of Rosenvingea is the tropical species $R$. nhatrangensis, which was first described by Dawson (1954) from Nha Trang, Vietnam. The species is distinguished from other Rosenvingea based on its terminally rounded, short ultimate branches as well as plurangia that form rounded sori around hair tufts. Despite its supposed wide distribution in the Indo-Pacific [i.e., India (Silva et al. 1996), Papua New Guinea (Littler \& Littler 2003), New Caledonia (Payri 2007), and Western Australia (Huisman et al. 2018)], the species is rarely reported even from its type locality. In their survey of the benthic algae of the coast of Nha Trang, Abbott et al. (2002) were not able to recover $R$. nhatrangensis. Similarly, in the molecular-based survey of Lee et al. (2014) on the diversity of Rosenvingea from Vietnam, they only found two Rosenvingea species, $R$. intricata and $R$. orientalis. Tsutsui et al. (2005), however, reported on the occurrence of the species from Duong De, Nha Trang. This present study contributes to the understanding of the taxonomy $R$. nhatrangensis by describing the morpho-anatomy of the species based on collections from Puerto Galera, Philippines and Tanjong Bidara, Malacca, Malaysia. Additionally, we report on the occurrence of $R$. australis in the Philippines based on the molecular information and morphology in culture of a sporophytic thallus collected from Cabilao Is., Bohol. 


\section{Materials and Methods}

Morphological observations under stereomicroscope were made on specimens of $R$. nhatrangensis deposited at the G.T. Velasquez Phycological Herbarium (MSI), The Marine Science Institute, University of the Philippines, Diliman, Quezon City. Transverse sections for anatomical observations were made similar to those described in Santiañez et al. (2018b), except these were mounted in corn syrup with a drop of phenol. Mounted specimens were examined under Motic BA410 microscope, and photographed using a microscope-mounted camera, Moticam 580 (Motic Incorporation Ltd., Hong Kong). Measurements were made using ImageJ 1.50i (Schneider et al. 2012).

Five years ago, Heroen Verbruggen (University of Melbourne) gave JW a live tiny tunicate with a green algal endosymbiont obtained by scuba diving at Cabilao Island, Bohol, Philippines on 11 May 2014. The tunicate and its symbiont died but several algae secondarily developed in the culture system of JW in Melbourne and were isolated including unidentified greens of the Siphonocladales and Derbesiales, red algae including Ceramium sp., Stylonema alsidii (Zanardini) K.M. Drew, Haloplegma duperryi Montagne, and a small filamentous brown alga (culture 4843-6) identified by WJES with molecular data in 2018 as $R$. australis. This alga was carefully observed for four years growing in Modified Provasoli's Medium (West 2005), under the following conditions: $18-22^{\circ} \mathrm{C}, 10: 14 \mathrm{hr}$ LD daily, LED lighting of lower intensity $\left(2-5 \mu \mathrm{mol}\right.$ photons $\left.\mathrm{m}^{-2} \mathrm{~s}^{-1}\right)$ in $75 \times 97 \mathrm{~mm}$ Pyrex deep storage dishes or $50 \times 70 \mathrm{~mm}$ dishes with stationary culture.

For observing culture 4843-6 ( $R$. australis), a Zeiss stereomicroscope equipped with KL1500 LCD lighting (Schott AG, Mainz, Germany) and a Zeiss GFL compound microscope (both microscopes: Carl Zeiss AG) were used. Microphotography was done on both microscopes with a Canon G3 and figures done using Photoshop CS5 Extended.

For molecular analyses, DNA extraction, PCR amplification, and sequencing of the mitochondrial $\operatorname{cox} 3$ and plastid psaA genes from $R$. australis followed the methods described in Santiañez et al. (2018b). We did not attempt to conduct DNA analyses on $R$. nhatrangensis as, aside from being at least 48 years old, these have been treated with formalin. Based on previous experience, old and/or formalin-treated scytosiphonacean specimens do not yield good quality DNA sequence data that can be used for molecular analyses. The newly generated cox 3 and $p s a \mathrm{~A}$ sequences of $R$. australis were aligned with published sequences of some scytosiphonacean taxa deposited in GenBank. Phylogenetic tree reconstruction using Maximum Likelihood (ML) and Bayesian analysis under the GTR $+\mathrm{I}+\Gamma$ model also followed those described in Santiañez et al. (2018b).

\section{Results and Discussion}

\section{Rosenvingea nhatrangensis E.Y. Dawson}

Holotype: US 00165050 (= Dawson 11170; photograph!), Cua Bé near Truong Dông, Nha Trang, Vietnam (Dawson 1954); deposited in US.

Distribution: Vietnam (Dawson 1954, Tsutsui et al. 2005), India (Silva et al. 1996), Papua New Guinea (Littler and Littler 2003), New Caledonia (Payri 2007), Western Australia (Huisman et al. 2018), Philippines and Malaysia (this study).

Observations: Thalli light brown, less than $5 \mathrm{~cm}$ long (Figs. 1A-B), thin-walled, sparsely branched, to three orders of branching. Branches to $1.2 \mathrm{~cm}$ wide, ultimate branches short (to $6 \mathrm{~mm}$ long) and narrow (2-4 mm wide), apices rounded. In fertile materials, plurangia distinctly arranged in oval sori (Fig. 1C), surrounding tufts of hairs (Fig. 1D). In cross-section, hollow branches bordered by a single layer of pigmented cortical cells (Fig. 1E), these broadly rounded to ovoid, 5-8 $\mu \mathrm{m}$ long, 6.5-10 $\mu \mathrm{m}$ wide; and 1-2 (3?) layers of large clear cells (Fig. 1E). Plurangia clavate, short, 8-11 $\mu \mathrm{m}$ long, loosely arranged in vertical palisades (Fig. 1E), quadriseriate, each with four locules (Fig. 1F).

Specimens examined: Philippines: MSI 2835 (A-C), 21 April 1970, Small Balatero, Puerto Galera, Oriental Mindoro, collected by G.C. Trono Jr. Note: Two sheets bear the number code 2835; two specimens were mounted on one sheet while the other only has one specimen. Malaysia: MSI 12077, 17 February 1965, Tanjong Bidara, Malacca, Malaysia, collected by H.M. Burkill (HMB 3759). Note: Three small specimens were mounted on the sheet; the largest and well-developed sample was included herein as Fig. 1B.

Remarks: The habit of Rosenvingea specimens from Puerto Galera, Philippines we examined in this study closely resembles the holotype specimen of $R$. nhatrangensis as illustrated by Dawson (1954, Fig. 19b). The morpho-anatomical features of the specimens also suggest close similarities with the original descriptions of the type (Dawson 1954), except the Philippine specimens have shorter and thinner ultimate branches, smaller medullary cells, and shorter plurilocular sporangia. The fertile Rosenvingea specimens from the Philippines similarly possess the distinctive round sori characteristic of $R$. nhatrangensis. As 

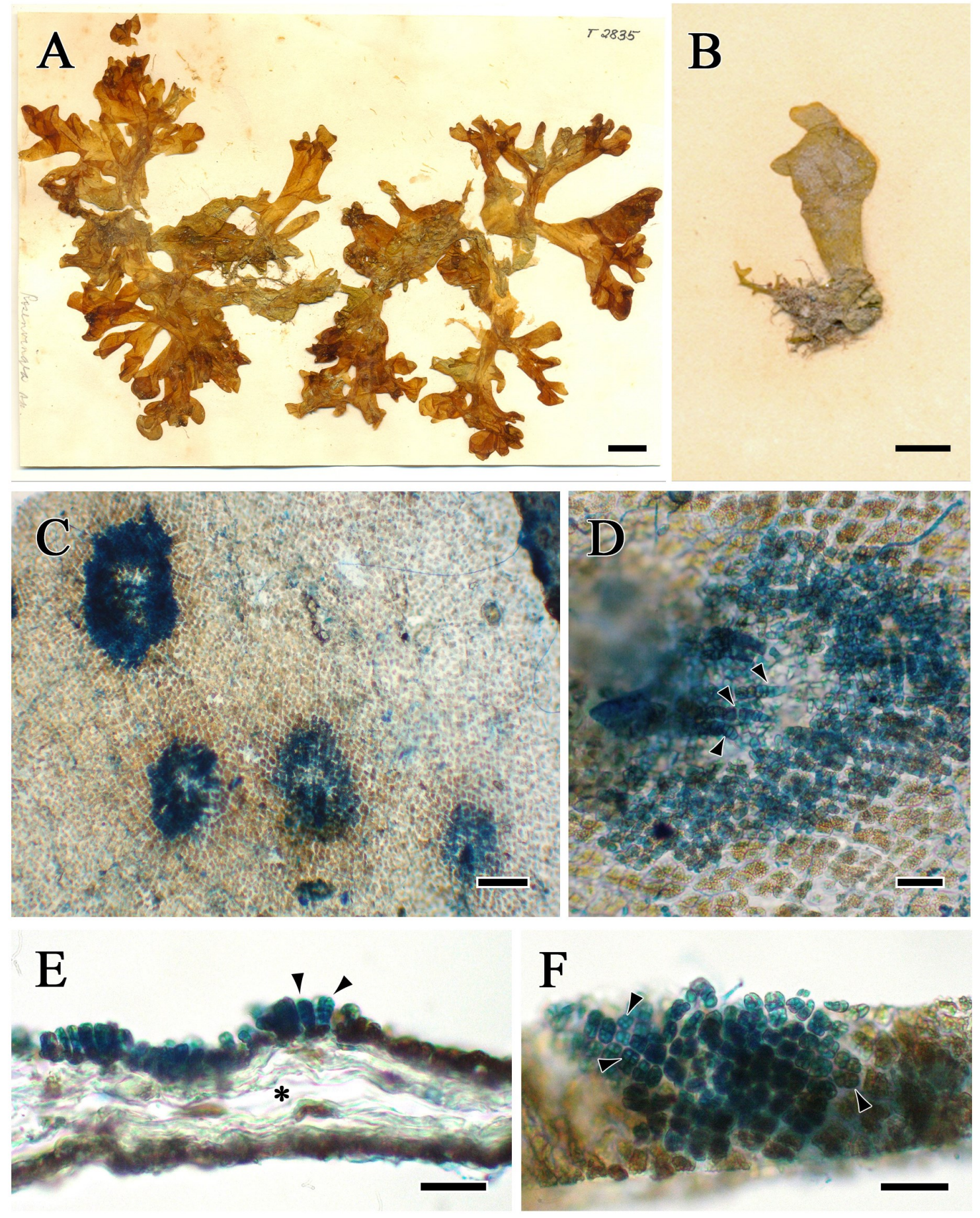

Figure 1. Rosenvingea nhatrangensis E.Y. Dawson. (A) Habit of specimen collected from Puerto Galera, Philippines (MSI 2835-A) showing branches with rounded apices. Scale bar $=1 \mathrm{~cm}$. (B) Young thalli collected from Malacca, Malaysia. Scale bar $=50 \mathrm{~mm}$. (C) Surface of fertile thallus showing oval plurangial sori surrounding a sterile center where tufts of hairs arise. Scale bar $=100 \mu \mathrm{m}$. (D) Phaeophycean hairs (arrowhead) that developed from shallow depressions in the surface of the thallus. Scale bar $=25 \mu \mathrm{m}$. (E) Transverse section through the fertile portion of the thallus showing hollow center (asterisk) and aggregates of short, clavate, and quadriseriate plurangia arranged in vertical palisades (arrowheads). Scale bar $=25 \mu \mathrm{m}$. (F) Surface view of quadriseriate plurilocular sporangia (arrowheads). Scale bar $=25 \mu \mathrm{m}$. 

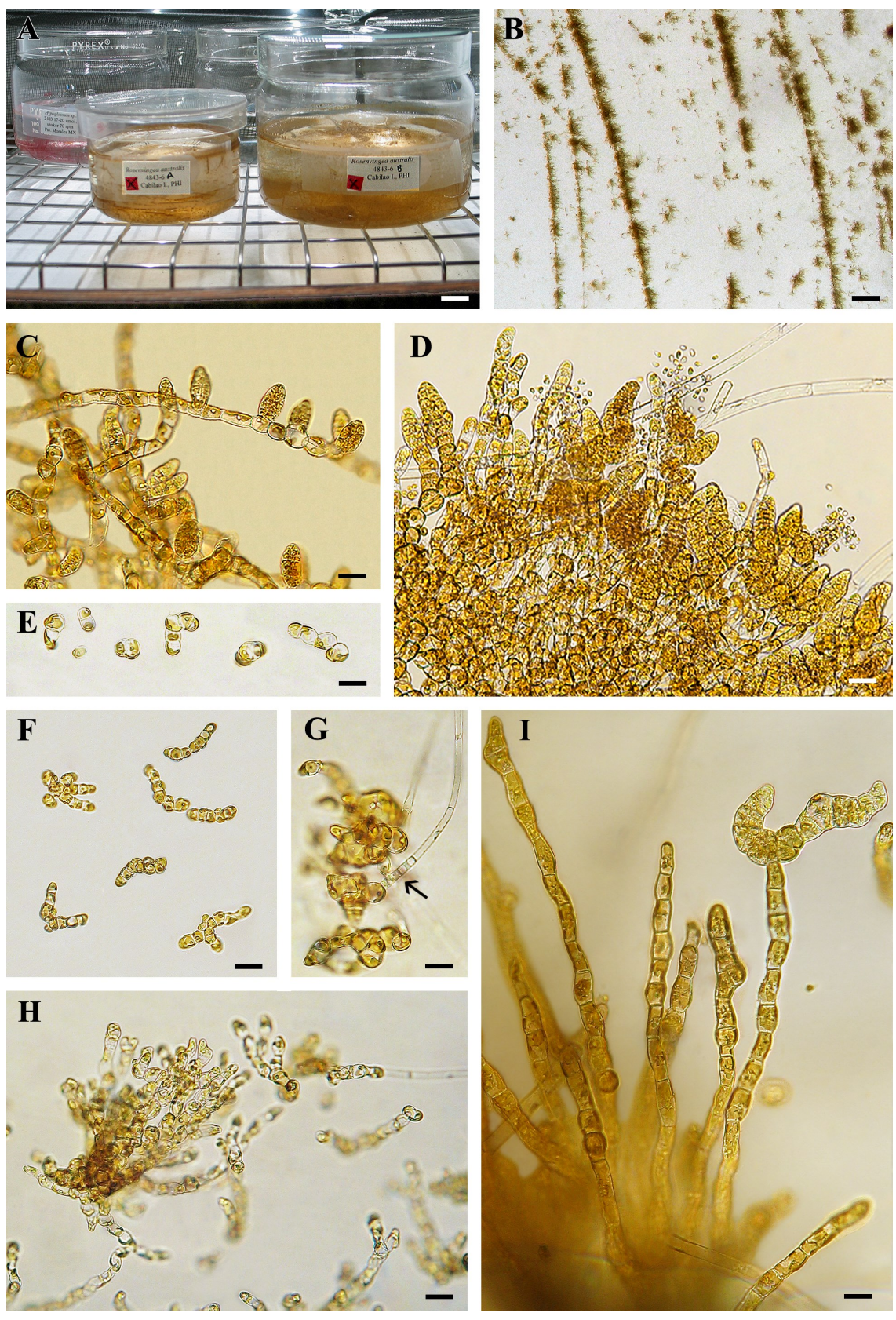

Figure 2. Rosenvingea australis Huisman, G.H. Boo \& S.M. Boo. (A) One month old cultures in small and large (10 cm wide) dishes, shaker $70 \mathrm{rpm}$, LED 17-20 $\mu \mathrm{mol}$ photons $\mathrm{m}^{-2} \mathrm{~s}^{-1}, 10: 14 \mathrm{LD}$ daily. Four 3-4 mm long filaments with plurangia were inoculated in each dish. Spore release and germination resulted in very dense growth. Scale bar $=1.25 \mathrm{~cm}$. (B) Spores prefer attaching to scratch-grooves in glass bottom forming long dense growth streaks. Scale bar $=2.5 \mathrm{~mm}$. (C) Obconical sessile elongate plurangia (15-20 $\mu \mathrm{m}$ diameter and 25-30 $\mu \mathrm{m}$ long), 6-10 locule rows long and 4-6 rows across, developing from intercalary cells and branch tips. Scale bar $=17.5 \mu \mathrm{m}$. (D) Large masses of densely branched vegetative filaments produce elongate colorless phaeophycean hairs and large numerous plurangia releasing abundant swimming spores (3-5 $\mu \mathrm{m}$ long). Scale bar $=25 \mu \mathrm{m}$. (E) Filamentous sporelings becoming $2-5$ cells long in $3 \mathrm{~d}$. Scale bar $=15 \mu \mathrm{m}$. (F) At 5-7 d, sporelings show vigorous branching. Scale bar $=20 \mu \mathrm{m}$. (G) Young branched thalli form phaeophycean hairs (to $700 \mu \mathrm{m}$ long), these developing from a basal meristem (arrow) originating from intercalary cells. Each vegetative cell has a lobed single plastid with at least one pyrenoid. Scale bar $=30 \mu \mathrm{m}$. (H) Well attached thalli often have many close, somewhat coalescent multibranched filaments. Scale bar $=50 \mu \mathrm{m}$. (I) Occasionally terminal cells of elongate unbranched filaments form irregularly shaped elongate structures that may be developing plurangia. Scale bar $=12.5 \mu \mathrm{m}$. 


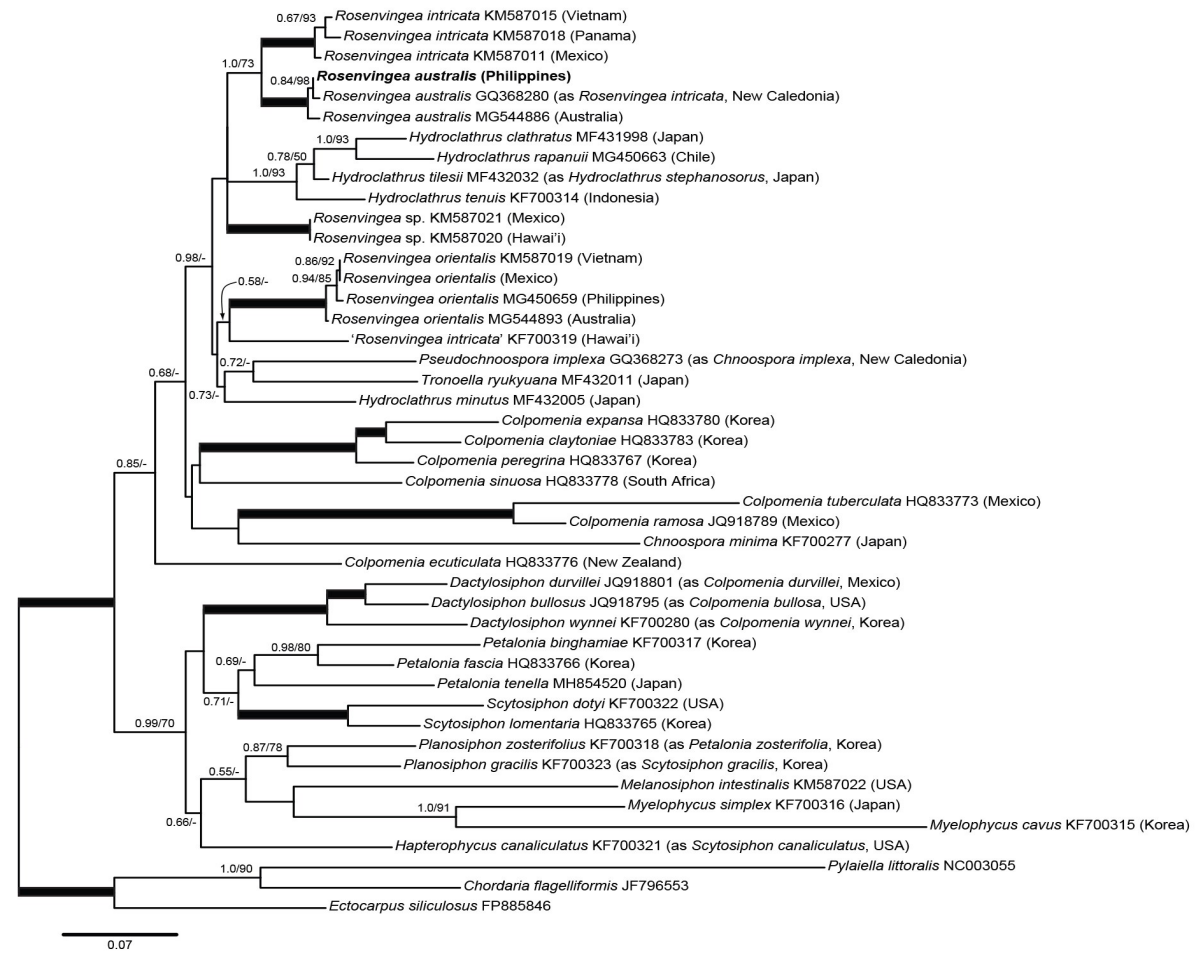

Figure 3. Maximum Likelihood (ML) phylogenetic tree for members of the family Scytosiphonaceae based on $\operatorname{cox} 3$ gene sequences. Bayesian posterior probabilities (PP) and ML bootstrap percentages (BP) are shown at each node, respectively. Thickened lines indicate highly supported nodes (PP: $\geq 0.98$ and BP: $\geq 95 \%$ ) are indicated by thickened lines. Values $<50 \% \mathrm{BP}$ and $<0.50 \mathrm{PP}$ are removed.

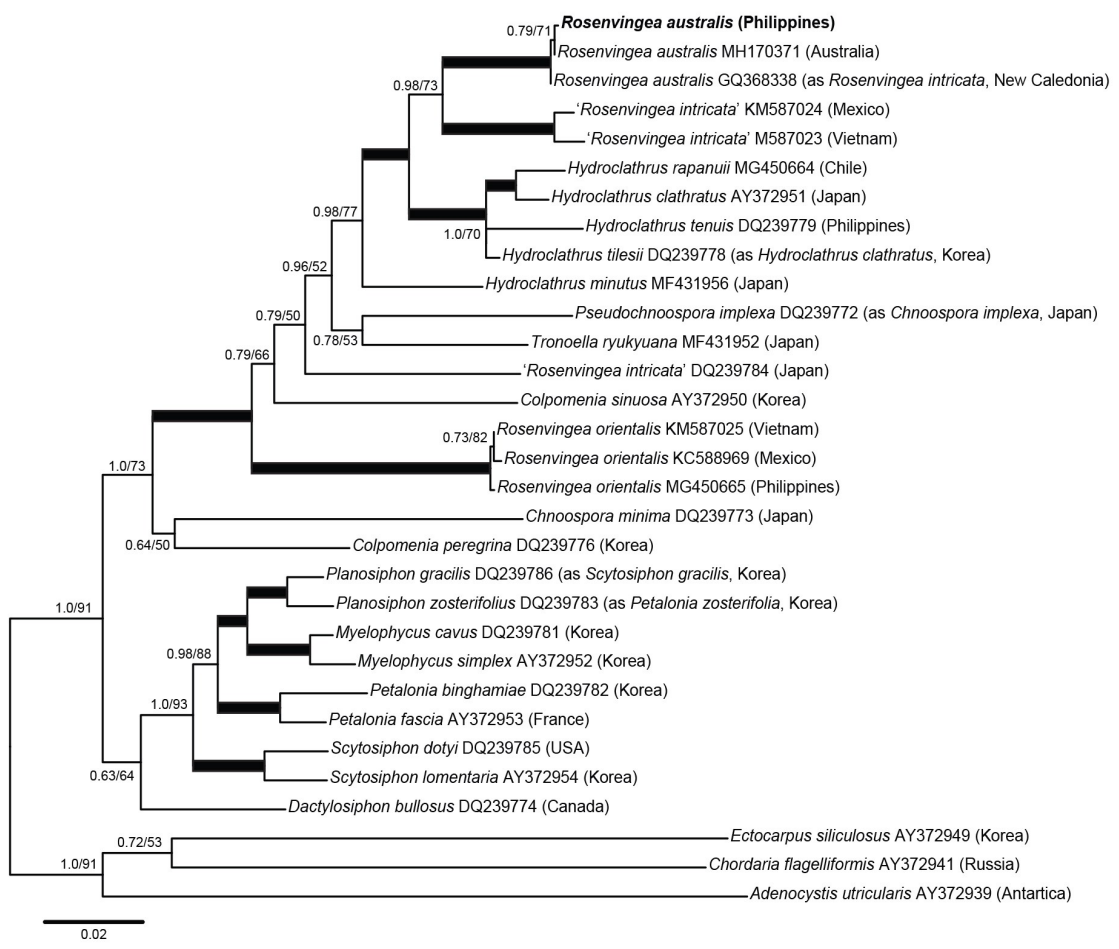

Figure 4. Maximum Likelihood (ML) phylogenetic tree for members of the family Scytosiphonaceae based on $p s a \mathrm{~A}$ gene sequences. Bayesian posterior probabilities (PP) and ML bootstrap percentages (BP) are shown at each node, respectively. Thickened lines indicate highly supported nodes (PP: $\geq 0.98$ and BP: $\geq 95 \%$ ) are indicated by thickened lines. Values $<50 \% \mathrm{BP}$ and $<0.50 \mathrm{PP}$ are removed. 
such, the specimens are herein attributed to $R$. nhatrangensis.

Rosenvingea nhatrangensis remains an elusive taxon and reports of its occurrence in other localities remain scanty. Our study adds the species to the flora of the two countries, the Philippines and Malaysia, and we believe that the species may be distributed in other areas within the tropical western Pacific. Possibly, the species has been overlooked both in the field and in herbarium collections as is the case in this study. This scenario is also similar to that of Hydroclathrus tilesii (Endlicher) Santiañez \& Wynne (=H. stephanosorus Kraft in Kraft and Abbott (2003)), a species frequently misidentified as H. clathratus (C. Agardh) Howe. For example, after surveying the morphologies of Hydroclathrus collections deposited at the Herbarium of the Faculty of Science, Hokkaido University, Sapporo, Japan (SAP), Santiañez and Wynne (2019) suggested that several specimens of $H$. tilesii have passed off as $H$. clathratus. As such, a more detailed survey at least on the dried collections of several herbaria in the region and elsewhere in the world would also likely yield at least new species records in other localities.

\section{Rosenvingea australis Huisman, G.H. Boo \& S.M. Boo}

Holotype: PERTH 08846308-D, Cape Peron, Western Australia; deposited in PERTH (Huisman et al. 2018).

Distribution: New Caledonia, Western Australia (Huisman et al. 2018), and Philippines (this study).

Observations: Rosenvingea australis grows vigorously in all conditions tested as loosely branched filamentous thalli attached to glass or free floating at the air-water interface reproducing by plurangia and zoospores that recycle the same thallus. No unangia reproduction or differentiation into any typical tubular or blade stage of any Rosenvingea species was observed.

The isolate 4843-6 grows prolifically in our culture facilities behaving like a contaminating marine weed. Nonetheless, it presented a genetic puzzle to solve, i.e. what was its molecular phylogeny? Initially it appeared to be of the order Ectocarpales in which a large widespread series of invasive browns are known. However, the morphological characters of 4843-6 - openly branched filaments, phaeophycean hairs, typical ectocarpalean cellular details, numerous plurangia producing spores that recycle the same thallus repeatedly—offer no certain taxonomic clues.

Since no typical Rosenvingea thallus, either tubular or flattened blade, was discernible in stationary culture under low light, it was transferred to two dish types $(75 \times 97 \mathrm{~mm}$ Pyrex deep storage dishes or $50 \times 70 \mathrm{~mm}$ dishes) in high LED lighting
(17-20 $\mu \mathrm{mol}$ photons $\mathrm{m}^{-2} \mathrm{~s}^{-1}$ ) and on a shaker at $60-70 \mathrm{rpm}$ for one month (Fig. 2A). This resulted in no significant difference of morphology or reproduction. The spores (3-5 $\mu \mathrm{m}$ long) have typical heterokont flagellation, germinate vigorously, preferentially seeking grooves of scratched glass and forming long dense rows of coalescing sporelings (Fig. 2B). Within 2-3 d, sporelings are $2-4$ cells long (Fig. 2E) and begin extensive branching in 5-7 d (Fig. 2F). Extensively branched filaments had numerous obconical, elongate, sessile plurangia (15-20 $\mu \mathrm{m}$ wide and 25-30 $\mu \mathrm{m}$ long), with many locule rows in length and width (Figs. 2C, D). Many phaeophycean hairs with basal meristems arise from intercalary cells (Fig. 2G). Spores were actively released in mass when filaments were placed on slides for microscopic observation (Fig. 2D). Loosely coalescent multibranched filaments (Fig. 2H) developed in some wellattached thalli but no defined blades or tubes typical of Rosenvingea developed. Occasionally, anomalous structures formed at tips of filament apices and resembled developing plurangia (Fig. 2I) but no mature plurangia were seen.

Remarks: Our observations here are made entirely with cultured specimens of $R$. australis from the Philippines. No other publications on $R$. australis have provided detailed evidence from cultured specimens. Our molecular phylogenetic reconstruction of the family Scytosiphonaceae based on cox3 and $p s a \mathrm{~A}$ sequence data (Figs. 3, 4) showed that our specimen (GenBank Accession Numbers MN224304 and MN224305, respectively) formed a distinct lineage together with the sequences of the type specimen from Western Australia and those from New Caledonia.

Rosenvingea australis was a newly described species from Cape Peron, Western Australia (type locality) and was also found in New Caledonia based on genetic information (Huisman et al. 2018). Our report extends the distribution of the species to the northern Pacific, particularly in Cabilao Is., Bohol, central Philippines. $R$. orientalis from Mexico had well developed blades in contrast to $R$. australis (West et al. 2010) in which upright thalli did not develop. In $R$. australis, we did not observe any unangia like those of ' $R$. intricata' (Kogame et al. 1999). Production of plurangia in prostrate sporophytic thalli is one of the common characters found among species within the 'Hydroclathrus group' sensu Santiañez et al. (2018a), as opposed to those found in the 'Scytosiphon group' which produce unangia only (Kogame et al. 1999).

\section{Conclusion and Recommendation}

Our current work on $R$. nhatrangensis provides the most recent taxonomic account of the species and extends its distribution to 
both the Philippines and Malaysia. Moreover, we also report for the first time the occurrence of $R$. australis in the northern Pacific based solely on molecular phylogenetic information as well as describing for the first time only its microscopic sporophytic form under culture conditions. Our current work suggests that several seaweed taxa remain 'hidden' to both Philippine science and society primarily due to the dwindling number and lack of expertise on seaweed biodiversity and systematics research. As such, we underscore the need to conduct more detailed work on Philippine algal biodiversity. Towards this end, we encourage working on local herbaria, especially on old (historical) collections, as these repositories hold a wealth of biodiversity information such as demonstrated herein. We would also advocate building reference seaweed culture collections in order for us to account for seaweeds that are otherwise overlooked in field surveys and collection efforts.

\section{Acknowledgements}

Heroen Verbruggen provided a field specimen from which $R$. australis was obtained in this study. Susan Loiseaux de Goër compiled Figure 2 using Photoshop 5S. We also wish to thank Christian Ace Guerta for his help in maintaining the live culture of $R$. australis at the Marine Science Institute (MSI). WJES acknowledges the Office of the Chancellor of the University of the Philippines Diliman, through the Office of the Vice Chancellor for Research and Development, for funding support in establishing and maintaining seaweed culture collections at the Marine Science Institute through the Ph.D. Incentive Award (Project No. 191926 PhDIA), the Balik Scientist Program of the Philippine Department of Science and Technology, and the Japanese Government's Ministry of Education, Culture, Sports, Science and Technology (MEXT) for the PhD scholarship grant. WJES is also indebted to Kazuhiro Kogame for guidance and support during his $\mathrm{PhD}$ at Hokkaido University. The herbarium specimens used in this study are courtesy of the G.T. Velasquez Phycological Herbarium of the Marine Science Institute, University of the Philippines Diliman. This is The Marine Science Institute Contribution No. 464.

\section{Literature Cited}

Abbott, I.A., J. Fisher \& K.J. McDermid, 2002. Newly reported species and revised marine algae from the vicinity of Nha Trang, Vietnam. In, Abbott I.A. \& K.J. McDermid (eds.), Taxonomy of Economic Seaweeds with reference to some Pacific species. VIII. pp. 291-321.

Børgesen, F., 1914. The marine algae of the Danish West Indies. Part 2. Phaeophyceae. Dansk Botanisk Arkiv, 2: 1-68.
Dawson, E.Y., 1954. Marine plants in the vicinity of the Institute Océanographique de Nha Trang, Viêt Nam. Pacific Science, 8: 372-469.

Guiry, M.D. \& G.M. Guiry, 2019. AlgaeBase. World-wide electronic publication, National University of Ireland, Galway. http://www.algaebase.org.

Huisman, J.M., G.H. Boo \& S.M. Boo, 2018. The genus Rosenvingea (Phaeophyceae: Scytosiphonaceae) in southwest Australia, with the description of Rosenvingea australis sp. nov. Botanica Marina, 61: 373-382.

Kogame, K., T. Horiguchi \& M. Masuda, 1999. Phylogeny of the order Scytosiphonales (Phaeophyceae) based on DNA sequences of $r b c \mathrm{~L}$, partial $r b c \mathrm{~S}$, and partial LSU nrDNA. Phycologia, 38: 496-502.

Lee, K.M., D.D. Hong \& S.M. Boo, 2014. Phylogenetic relationships of Rosenvingea (Scytosiphonaceae, Phaeophyceae) from Vietnam based on cox3 and psaA sequences. Algae, 29: 289-297.

Littler, D.S. \& M.M. Littler, 2003. South Pacific reef plants: a diver's guide to the plant life of the South Pacific coral reefs. Offshore Graphics, Inc., Washington, D.C., pp. 331.

Norris, J.N. 2010. Marine algae of the Northern Gulf of California: Chlorophyta and Phaeophyceae. Smithsonian Contributions to Botany, 94: 1-276.

Payri, C.E., 2007. Revised checklist of marine algae (Chlorophyta, Rhodophyta and Ochrophyta) and seagrasses (Marine Angiosperms) of New Caledonia. In: Payri, C.E. \& B. Richer de Forges, (eds.), Compendium of marine species from New Caledonia. Documents Scientifique et Techniques. 117. Sciences de la Mer. Ed. 2., NouvelleCalédonie: Centre IRD de Nouméa. pp. 95-112.

Santiañez, W.J.E., E.C. Macaya, K.M. Lee, G.Y. Cho, S.M. Boo $\&$ K. Kogame, 2018a. Taxonomic reassessment of the IndoPacific Scytosiphonaceae (Phaeophyceae): Hydroclathrus rapanuii sp. nov. and Chnoospora minima from Easter Island, with proposal of Dactylosiphon gen. nov. and Pseudochnoospora gen. nov. Botanica Marina, 61: 47-64.

Santiañez, W.J.E., K.M. Lee, S. Uwai, A. Kurihara, P.J.L. Geraldino, E.T. Ganzon-Fortes, S.M. Boo \& K. Kogame, 2018b. Untangling nets: elucidating the diversity and phylogeny of the clathrate brown algal genus Hydroclathrus, with the description of a new genus Tronoella (Scytosiphonaceae, Phaeophyceae). Phycologia, 57: 61-78.

Santiañez, W.J.E. \& M.J. Wynne, 2019. Evidence for the treatment of Talarodictyon tilesii as an older taxonomic synonym of Hydroclathrus stephanosorus (Scytosiphonaceae, Phaeophyceae). Phycological Research, 67: 82-85. 
Schneider, C.A., W.S. Rasband \& K.W. Eliceiri, 2012. NIH Image to ImageJ: 25 years of image analysis. Nature Methods 9: 671-675.

Silva P.C., P.W. Basson \& R.L. Moe, 1996. Catalogue of the benthic marine algae of the Indian Ocean. University of California Publications in Botany, 79: 1-1259.

Taylor, W.R. 1955. Notes on algae from the tropical Atlantic Ocean, IV. Papers of the Michigan Academy of Sciences, Arts and Letters, 40: 67-76.

Tsutsui, I., Q.N. Huynh, H. Dinh Nguyen, S. Arai \& T. Yoshida, 2005. The common marine plants of southern Vietnam. Japan Seaweed Association, Kochi, Japan. 250 p.

West, J.A., 2005. Long Term Macroalgal Culture Maintenance, Chapter 11. In, Andersen R. (ed.), Algal Culturing Techniques. Academic Press, New York. pp. 157-163.

West, J.A., G.C. Zuccarello, F.F. Pedroche \& S. Loiseaux de Goër, 2010. Rosenvingea orientalis (Scytosiphonaceae, Phaeophyceae) from Chiapas, Mexico: life history in culture and molecular phylogeny. Algae, 25: 187-195.

Wynne, M.J., 1997. Rosenvingea antillarum (P. Crouan \& H. Crouan) comb. nov. to replace $R$. floridana (W.R. Taylor) W.R. Taylor (Scytosiphonales, Phaeophyta). Cryptogamie, Algologie, 18: 331-336. 